Toeris in Hillbrow: rubrieke.

Andries Bezuidenhout. Kaapstad: Human \& Rousseau, 2010. 192 pp.

ISBN: 978-0-798-15209-9.

DOI: http://dx.doi.org/10.4314/tvl.v49i1.28

Andries Bezuidenhout is onder meer bekend as "Roof" van die Brixton Moord en Rooforkes. In 2007 is sy debuutbundel gedigte Retoer deur Protea Boekhuis gepubliseer. Toeris in Hillbrow is 'n keur uit Bezuidenhout, die sanger-skrywer-sosioloog, se rubrieke wat meestal in Rapport verskyn het. Deesdae is daar baie rubriekskrywers wat vir die hoofstroom Afrikaanse koerante skryf. Baie van die bydraes van rubriekskrywers soos Etienne van Heerden en meer onlangs Eben Venter het neerslag gekry in selfstandige publikasies. Die vraag ontstaan dus: kan 'n minder gevestigde skrywer soos Bezuidenhout dieselfde hoë peil handhaaf as die meer gevestigde romansiers? Die gereelde kort rubriek is 'n veeleisende genre wat selfs die beste skrywers kan uitput.

Een van die sterkste aspekte van die bundel is die groepering van die rubrieke. Hul tematies gemotiveerde plasing sorg dat die leser' $n$ meer genuanseerde blik op 'n situasie kry en knoop gesprekke tussen die rubrieke aan. Begin byvoorbeeld by "As die nuwe Natte breek en bou" (150) en eindig met "Die nuwe taalstryd" (163) en 'n mens word op 'n reis deur die kulturele kwessies van ons tyd meegesleur.

As'n mens oor reise praat, is die titel sekerlik die volgende pluspunt van die bundel. Die bundel gaan nie soseer oor Hillbrow nie, maar oor die idee dat weens verskeie faktore Bezuidenhout' $n$ buitestander, $n$ toeris is in die buurt wat hy sy "huis" noem. Hierdie buitestandermotief word dan uitgebrei tot 'n hoogtepunt in die rubriek "Kersfees as toeris in Hillbrow" waarin blankes as permanente toeriste in hulle eie land bestempel word, die stranger withinmotief. Uit hierdie tema, vloei dan die ander beduidende temas: die verlede teenoor die hede; die stad teenoor die plattelandse dorpe. Ek vermoed dat die naam Hillbrow vorentoe die bundel se sterkste punt gaan wees omdat Hillbrow 'n ikoniese ruimte binne die SuidAfrikaanse literêre sisteem verteenwoordig net soos die Soweto's, Sophiatowns en Distrik Sesse van Suid-Afrika.

Wat die reistema betref, is ek van mening dat Bezuidenhout beslis die manlike ekwivalent van 'n Joan Hambidge is vir wie reis ' $n$ kreatiewe stimulus is. Ek was aanvanklik huiwerig om hierdie boek te resenseer gedagtig aan Alan Paton wat altyd Johannesburg as 'n "land without sea and mountains" beskryf het (om nie eers van Hillbrow te praat nie!). Hoe wonderlik dan was dit nie om in die voetspore van hierdie flaneur te stap-vanaf Amsterdam tot Johannesburg, die Krugerwildtuin en deur die hele Karoo-Richmond, VictoriaWes, Beaufort-Wes en Trompsburg waar Bezuidenhout sy wegbreekhuisie het. Bezuidenhout is ongetwyfeld wat ek noem 'n "Karooster". Hy ken al die belangrike skrywers en kunstenaars van die Karoo-Gert Vlok Nel en Beaufort-Wes; Karel Schoeman en Trompsburg; Schreiner en haar Karoo; A. G. Visser en Steytlerville; Helen Martins en Nieu-Bethesda. Maar dis ongetwyfeld die sensitiwiteit, die meegevoel van die skrywer wat' $n$ mens lank na die eksterne reis bybly. Lees in hierdie verband "Toe daar nog rus in Rustenburg was".

Bezuidenhout is ongetwyfeld ook ' $n$ man met'n skerp sin vir humor. "Die evolusie van spesies" is ongetwyfeld by uitstek die rubriek wat hierdie punt illustreer. Boonop moet ' $n$ rubriekskrywer nie net beskrywend wees nie, maar moet ' $n$ uitsonderlike verbeelding verder die hoeksteen van sy skryfwerk wees. "Die jagter-versamelaars van name, woorde en wysies" en "Hoe om 'n land te verlaat" was vir my die uitblinkers in hierdie verband. En elke nou en dan soek ek' $n$ frase uit 'n bundel wat die bundel onvergeetlik maak. Ek dink ek het dit gevind in die reël: "Die geskiedenis het nie 'n herfs of 'n lente nie" (121). 
Maar vir' $n$ buitestander soos ek wat nie in 'n Afrikaanse gemeenskap grootgeword het nie, was die musiekgeskiedenis vir my fassinerend. As 'n "nuweling" tot die Afrikaanse kultuur was dit insiggewend om meer te leer oor Johannes Kerkorrel, Koos Kombuis, Valiant Swart, Anton Goosen, Gert Vlok Nel, Fokofpolisiekar en David Kramer. Maar nie oor die agter-die-skerms-stories oor alkoholgebruik en seks nie, maar eerder oor hulle lirieke en die rol wat daardie lirieke gespeel het in die Afrikaanse kultuur. Hierbenewens is daar die verskynsel van die assosiasies van liedjies vir amper elke dorp in Suid-Afrika.

Iemand het eenkeer geskryf: "Journalism is literature in a hurry." Hierdie oordeel kan glad nie oor Toeris in Hillbrow van Andries Bezuidenhout gefel word nie. Hierdie bundel as uitvloeisel van die joernalistiek is definitief literatuur en verdien beslis om wyd gelees te word.

\section{Darryl David}

Universiteit van KwaZulu-Natal

Durban 